\title{
Between Lyric and Epic: The Great Turkish War in German, Italian and Hungarian Ereignisliedern
}

\author{
Levente Seláf
}

In his outstanding work on Popular Culture in Early Modern Europe, Peter Burke dedicated a lengthy chapter to the different literary genres characteristic of that period. As he observes,

One of the most important of these [genres] is the narrative song, which it is convenient to call 'ballad' or 'epic' (according to length), although the singers themselves were more likely to use simpler terms like 'songs' (Danish viser, Serbian pjesme), 'stories' (the Spanish romances), or 'old things' (Russian stariny). ${ }^{1}$

In the course of his presentation, Burke refers among other genres and exemplars to the Hungarian report songs. His examples are Tinódi's Siege of Eger, together with the English Gest of Robin Hood and the Italian cantare I Reali di Francia, as well as several German and Scandinavian ballads.

For Burke as an historian of mentalities, the differences between various types of literary expression are less important than the presentation of

a few basic types of artefact and performance. They are never quite the same in any two regions, but they are not all that different either: unique combinations of recurrent elements, local variations on European themes. $^{2}$

The poetic features of the narrative songs are described in a very succinct way by Burke. He remarks on the great variety of the metrical and musical forms used in different language areas: this diversity allows him to identify some sub-groups (such as Slavic or Romance epic songs), but no extralinguistic connections are mentioned. Beside the need of a narrative line for these poems,

1 Burke (1994) 118.

2 Burke (1994) 116. 
the fact that 'narrative song was of no fixed length' is the only proof offered for the community of this genre all over Europe. Literary historians will hardly be satisfied with this approach, even if one cannot deny some similarity between all these poems. But they are not unique in this respect: if one wanted, the fact that narration is combined with melodic performance could also join pieces as disparate as the eleventh-century Chanson de Roland and the nineteenthcentury Hungarian or Rumanian folk ballads.

We aim to get closer to this book's goal (circumscribing the uses of lyrical poetry in the fifteenth-seventeenth centuries) by the analysis of a subset of narrative or epic song, this very broad 'genre' identified by Burke in so many and so different literatures. ${ }^{3}$ I will try to catch the similarities between some important literary phenomena of the period, as they are present in at least three European literatures: Hungarian, German, and Italian. Using a single historical episode, a report of a military conflict between Christians and Turks, as my point of departure, I will involve in my comparison several poems in different languages that might or might not be called lyric in different literary traditions. Formal and thematic criteria link these poems one to the other, in spite of their distance from one another in time, language and space. They are all characterized by the use of polemical discourse to describe military confrontation between two antagonistic forces, from the point of view of one of the participants. Regarding the formal aspects, only strophic poems will be compared with each other. ${ }^{4}$ The main purpose here is to show just how similar the topics articulated in sixteenth-century Hungarian, German and Italian poetry were, and to ask also whether we can posit a direct influence upon Hungarian literature, still young at the time, an influence that may have been exerted by one or both prestigious poetic traditions. Of course, German and Italian poems are not the only potential structural and thematic parallels to the Hungarian report songs. In another article I examined shortly the resemblance and disparity of the Spanish canciones noticieras with that genre, and in still another I presented the common and different features of Czech, German and Hungarian historical

3 It is of course difficult if not impossible to give a coherent definition of lyrical poetry that is valid for all national literatures. In my experience, definitions of "lyrical poetry" are almost as diverse and contradictory as the different philological traditions. When discussing the phenomenon of lyrical poetry in medieval and early modern literature, the situation is rendered even more complicated because the concept of the lyric was either ignored or interpreted in a very narrow sense throughout this period. The texts I present here may be called lyric mostly by virtue of their strophic structure and their possible sung performance.

4 No texts in rhyming couplets (like the German Reimreden) will be treated, because their poetical organisation is minimal, and because this form apparently excluded the possibility of performing the text with melody in all European literary traditions. 
songs dedicated to the battle of Mohács against the Turks in 1526, causing the death of Louis II, king of Bohemia and Hungary. ${ }^{5}$ Here I will restrain the scope of my inquiry to the relationship between Hungarian, Italian and German texts.

Rolf Wilhelm Brednich dedicated an important work to the phenomenon of Liedpublizistik in early modern German literature. ${ }^{6} \mathrm{He}$ offers a useful definition of the historisches Ereignislied and the Zeitungslied, the two German genres close to the Hungarian and Italian poems to be presented in this paper. More recently, Karina Kellermann has elucidated the characteristics of the genre while redefining it as historisch-politische Ereignisdichtung. ${ }^{7}$ Their observations will form the background of the analyses throughout this paper.

\section{Hungarian Poetry in Context}

In order to test the validity of a large-scale comparison like Burke's, it is worth listening to some Renaissance literary theorists who wrote with some claim to veracity on Hungarian poetry and gave a definition of what we would call historical poetry.

The first contextualisation of Hungarian poetry by a foreign observer can be found in Sir Philip Sidney's Defence of Poesie:

Is it the Lyricke that most displeaseth, who with his tuned Lyre and well accorded voice, giveth praise, the reward of vertue, to vertuous acts? who giveth morall preceptes and naturall Problemes, who sometimes raiseth up his voyce to the height of the heavens, in singing the laudes of the immortall God? Certainly I must confesse mine owne barbarousnesse, I never heard the old Song of Percy and Duglas, that I founde not my heart

5 Seláf 2014; Seláf 2016.

6 Primarily Brednich (1974-1975), and also Brednich (1982-1983).

7 Kellermann (2000). For the sake of brevity and simplicity this paper still employs the term "historisches Ereignislied" referring to the German genre, and the same or "report song" while referring to Hungarian poems. While it fully recognizes the merits of Kellermann's work, this paper, as the argumentation and the corpus shows, will argue against some aspects of her approach. She does not consider the specificity of strophic form, instead combining texts written in rhyming couplets and strophic texts into one category. In Hungarian there is only one "historico-political poem" in rhyming couplets: the Battle of Szabács from the 1470's, the earliest specimen of the genre, probably composed by a Germanophone author who learnt Hungarian, see Horváth (2009) 151-156. A second, minor issue arises from the circumstance that the chronological framework of her corpus does not correspond to that of report songs in Hungarian poetry, so that it is useful to keep in mind equally Brednich's results obtained from early modern printed texts. 
mooved more than with a Trumpet; and yet is it sung but by some blinde Crowder, with no rougher voyce, than rude stile: which being so evill apparelled in the dust and Cobwebbes of that uncivill age, what would it worke, trimmed in the gorgeous eloquence of Pindar? In Hungarie I have seene it the manner at all Feastes and other such like meetings, to have songs of their ancestors valure, which that right souldierlike nation, think one of the chiefest kindlers of brave courage. The incomparable Lacedemonians, did not onelie carrie that kinde of Musicke ever with them to the field, but even at home, as such songs were made, so were they all content to be singers of them: when the lustie men were to tell what they did, the old men what they had done, and the yoong what they would doo. And where a man may say that Pindare many times praiseth highly Victories of small moment, rather matters of sport then vertue, as it may be answered, it was the fault of the Poet, and not of the Poetrie; so indeed the chiefe fault was, in the time and custome of the Greekes, who set those toyes at so high a price, that Philip of Macedon reckoned a horse-race wonne at Olympus, among his three fearfull felicities. ${ }^{8}$

In his Defence Sidney enumerates all poetical classes and genres; here, while defending lyric poetry, he insists on the virtue of unpolished songs that commemorate historical facts by evoking the warlike deeds of the ancestors and encouraging the warriors. Sidney refers to Hungarian historical poetry as a contemporary example, while all his other examples are either antique or, in the exceptional case of the Ballad of Chery Chase, belong to the venerable medieval past of English poetry. ${ }^{9}$ The disparity between the literatures from which he takes his references is conscious and serves to support his argument all the more effectively. For him, epic (Heroicall) poetry is clearly distinct from the historical poetry presented in the above-cited paragraph, as there is a separate paragraph devoted to it.

It is perhaps surprising that Sidney should have noticed the existence of Hungarian poetry, and heard some performances of it during his court stay in the country. In fact the type of poetry he mentions fits what we know about this tradition. It supports the testimony of the Italian humanist Galeotto Marzio, who stayed from 1461 to 1487 at the court of King Mathias Corvinus, and described Hungarian poetry in very similar terms.

8 An electronic edition of the first edition published by Ponsonby in 1595 is available under https://scholarsbank.uoregon.edu/xmlui/handle/1794/816.

9 Sidney travelled through Hungary in 1573 and witnessed the conflict between Turkish and Habsburg royal armies. 
When [King Mathias, L.S.] dines, there is always discussion of some uplifting or lighthearted topic, or else a song is sung. And there are always musicians and cithara-players present at table, who sing the high deeds of the worthies in the vernacular, accompanied by the lyre. This was the custom of the Romans, and then it was passed from us to the Hungarians. They always sing of some outstanding exploit, nor is there any shortage of subject matter. For since Hungary is situated in the midst of different enemies speaking different languages, there is always an opportunity to fight in a war. They rarely sing love songs there, and, as most of the time they fight against the Turks, their songs are not without texts. ${ }^{10}$

The striking similarity of the two descriptions suggests either that Sidney has borrowed from Galeotto's work, or that they are describing cognate phenomena. ${ }^{11}$ The chief difference is that while Sidney says that Hungarians sing about the glorious past, Galeotto tells us that they sing about recent events of the war. Not enough texts have survived from the fifteenth century for us to judge the character of Hungarian literature at the time, but scholars assume that

10 "Semper enim in eius [sc. regis Mathiai] convivio disputatur aut sermo de re honesta aut iocunda habetur aut carmen cantatur. Sunt enim ibi musici et citharoedi, qui fortium gesta in lingua patria ad mensam in lyra decantant. Mos enim Romanorum hic fuit et a nobis defluxit ad Hungaros. Cantatur autem semper aloquod egregium facinus nec deest materia. Nam cum Hungaria in medio hostium diversarum linguarum sita sit, semper rei bellicae habet formitem. Amatoria autem carmina raro ibi cantantur et, ut plurimum gesta in Turchos in medium veniunt, non sine sermone concinno." (Juhász (1934) 18). As Galeotto was very close to Matthias and dedicated his work to John Corvinus, the king's son, his observations cannot be taken for the observations of an outsider. Galeotto goes on to say that there is no difference between the Hungarian spoken by peasants and noblemen, both of whom understand the songs: "Hungari enim sive nobiles sive rustici sint, eadem fere verborum condicione utuntur et sine nulla carietate loquuntur, eadem enim pronuntiatio, eadem vocabula, similes accentus ubique sunt. [...] Sed apud Hungaros, ut diximus, eadem loquendi forma vero exigua admodum differentia est, unde fit, ut carmen lingua Hungarica compositum rusticis et civibus mediis et extremis eodem tenore intelligatur" ("Indeed, whether they are noblemen or peasants the Hungarians use almost the same style of language and speak without worry; pronunciation, vocabulary and accent are everywhere the same. [...] But as we have said, there is truly very little difference in the forms of speech, so that a song composed in the Hungarian language can be understood in one idiom by countrymen and in the towns, whether they are central or outlying.").

11 None of these testimonies inform us about the form of the poems. In this respect they are hardly different from Tacitus' brief statement, claiming that Germanic tribes have no annals or chronicles, but they sing poems on their ancient history. However, Galeotto and Sidney mention Hungarian poetry in a pure poetical context. 
Mathias' reign coincided with the beginnings of vernacular literary production. ${ }^{12}$ With regard to the sixteenth century, we can confirm that one of the most important genres of Hungarian poetry was narrative song that referred to an old or recent historical event, mostly taken from national history, and that celebrated a memorable deed, encouraging its listeners/readers by example.

Sidney is not the only Renaissance literary theorist for whom the category of historical poems was not simply equivalent to the heroic epic. The main difference between the two kinds of poetry was the role of fiction, which was a defining feature of the latter. For Renaissance observers, the common denominator in both categories was their exemplary function, as described for instance in George Puttenham's treatise, The Art of English Poesy. For him, Plato's Republic, the Iliad and the Odyssey, Xenophon's Cyropaedia and Thucydides' History of the Peloponnesian War, the Arthurian verse romances and the chansons de geste all belonged to this type of poetry. But Puttenham mentions Pindar's and Callimachus' hymns and encomia in the same context, as 'not very [i.e. not true] histories but a manner of historical reports.' ${ }^{13}$ The looseness of this interpretation of what historical poetry is can help us to cast our nets widely in the search for reasons why lyric forms were suitable for religious and political propaganda in medieval and early modern Europe.

Almost without exception, Hungarian narrative poems of the sixteenth century were strophic. The genre of historical songs (históriás énekek, in fact "histories", or simply "stories in verses") is represented by about 18 o pieces of Hungarian poetry from 1530 to $1630 .{ }^{14}$ These poems could be sung to a melody, and they were all cast in a very simple strophic structure. The two most popular schemata were both monorhyme quatrains, one using eleven-syllable verses and other lines of twelve syllables. Philologists traditionally divide these poems into three different categories or sub-genera, according to their topic: a) biblical, b) strictly historical songs and c) those including a fiction in the plot (mostly adapted from Italian, Latin, Greek or German stories). As others have

The first known Hungarian poem, a planctus Mariae, is dated to the mid-thirteenth century. After a long silence, vernacular Hungarian literary texts of some length appear in the second half of the fifteenth century. For an account of the earliest documents in Hungarian see Madas (2009).

13 Whigham and Rebhorn (2007) 128-131.

14 There are some earlier poems on historical topics, but they are composed in rhyming couplets or use paraliturgical lyric structures. In their form, they do not fit the tradition first attested in the 1530 , and so they probably cannot be treated as its antecedents. In terms of volume, the corpus of históriás énekek comprises $10 \%$ of Hungarian poetry from before 1600. 
remarked, most are very homogeneous in their relationship to the source-text, in their didactic purpose, and in their use of a number of rhetorical devices, regardless of the nature of the text (of very different sources, from the Bible to Boccaccio) they translate and paraphrase. Contemporary references and general moral remarks can be found in every text: the biblical topics always offered the opportunity to comment on some recent historical event and on the doings of actors on the political scene. The converse is also true: biblical parallels could always be easily inserted into a poem dealing with national history. ${ }^{15}$ Apart from the prose chronicles, there were no real alternatives or rivals to this form in Hungarian literature at the time, either for historical topics or for narratives in general. The prose chronicles were written mostly in Latin, occasionally in Hungarian.

\section{$2 \quad$ Tinódi and the Hungarian Report Song}

In the following, I will concentrate on a rather small group of poems ( 26 pieces) dealing with a contemporaneous event, forming a sub-genre of the second category (b). These poems are called, in the Hungarian philological tradition, tudósitó énekek (report songs). In several respects, they resemble the German historische Ereignislieder. Some critics suppose that the Hungarian report songs were probably also published as broadsheets (Flugblätter), although the earliest surviving examples are conserved in larger printed song collections, and no separately published report song or strictly historical song is known from before the late sixteenth century. Presumably, before the mid-sixteenth century they were distributed mainly in manuscript form, and orally performed for a wider public, not least because of the scarcity of Hungarian printing houses. The analogies with German Liedpublizistik have long been noticed by literary historians, ${ }^{16}$ but today's scholarship does not support a direct German influence on Hungarian historical song. ${ }^{17}$

\footnotetext{
15 Orlovszky (2007).

16 Founding his arguments on Béla Pukánszky's analysis, it is Ferenc Zemplényi who has compared the two genres recently, attesting their stylistic similarities, the traces of oral performance in both, their closeness in time to the narrated events, and their similar relationship to the melodies. For him, their equivalence was beyond doubt, and he found a place for both types of poem in the popular register of poetry. Although these similarities are striking, the Hungarian report songs also have features in common with other Hungarian historical songs that cannot be explained in terms of German influence. See Zemplényi (1998) 48-56. 
As I have said, the origin of report songs is obscure, but it is clear that one author played an important role in establishing the most important characteristics of the genre: Sebastian Tinódi, a fiddler and probably a veteran soldier ennobled by the king in August 1553. Tinódi's life and career are largely unknown. He certainly studied in a Hungarian school, and he had a basic humanist training: in some acrostics he describes himself as a litteratus. More than half of the surviving examples of the genre ( 15 of 27 pieces) are attributable to Tinódi. Scholars generally assume that he pioneered such compositions in Hungarian. ${ }^{18}$ Although he also composed songs with biblical and fictional narrative plots, and historical poems of the Hungarian past, his major genre was the strictly historico-political and report song, commemorating the Turkish-Hungarian conflict, the never-ending war as a constant experience of his generation. He edited and published his songbook in 1554. It is dedicated to King Ferdinand of Habsburg, referring to Vergil's Aeneid and citing the hero who encouraged his companions by promising that their deeds and sufferings would be celebrated; in the same way, the Hungarian soldiers must look forward to being commemorated, and the king should find pleasure in reading news of the war.

No azért, felségös és kegyelmes uram, ezt gondolám magamba, hogy ez szegín Magyarországba az pogán terek császár miatt lött sok veszödelmekbe, és az felségöd vitézinek elesésökbe és vitézségökbe, nyereségökbe krónikába beírnék, kivel felségödnek hív szolgálatomat jelönteném és kedvét lelném, mert jól tudom az bölcs fejedelmeknek erkölcsöket, hogy minden újságnak írását örömest látják és olvassák. Vagy nyereség avagy veszteség, de róla megemléközni gyönyörűség. Tanubizonság erről az tengör vizébe Eneas társait mint biztatja volt, hogy az ott való nyomorúságok végre emléközetre öröm leszön.

That's why, Your Majesty, I remembered that poor Hungary suffered many disasters because of the pagan Turkish Emperor, and I wanted to write of your Majesty's soldiers' defeats, victories and courage in chronicles, wishing to please You and to serve You, being aware of the moral of the wise Princes who like to read and to see all kinds of novelties. Whether they are stories of gain or loss, to remember them is a pleasure. Proof of this is found in the way Aeneas encouraged his companions while they were 
wandering at sea, when he argued that the memory of their sufferings would cause joy and pleasure in the end. ${ }^{19}$

He says in his foreword that he either witnessed the events narrated or heard them from creditable witnesses, Christian knights participating in the conflict. While the truth of the narrated events is a literary topos, we can probably trust him, even if he adapted the experiences he narrates to fit the criteria of the historical song's wider genre. Tinódi composed most of his poems very close in time to the narrated events, while some others were produced after a greater lapse of time, when he compiled the songbook.

Tinódi's songbook (published in 1554) is in two parts. ${ }^{20}$ The first is a strictly linear chronological narration in eight songs of Hungarian political events from 1541 to 1554 . Their length varies from 81 to 449 strophes (longer poems are split into several cantos). One aspect of the careful composition of this first part gives it a strong similarity to rhyme-chronicles: the different songs contain explicit cross-references to each other. Probably for this reason, the author gave his collection the title Cronica. ${ }^{21}$ The second part compiles different songs written by Tinódi: some report songs that did not fit into the linear narrative, one on Western European history (the story of a revolt against the German emperor Charles v), biblical historical songs and some satirical poems. Probably he set his own poems to music: 22 melodies accompany his songbook, possibly originals. Some other poems by Tinódi are extant in manuscripts and later prints, either because they were composed after 1554 or because they were not suited to the character of the volume he wanted to compose. ${ }^{22}$ While in his earlier works Tinódi supported King John Szapolyai (d. 1541), Ferdinand's adversary as a pretender to the Hungarian crown, the newest poems of the songbook flatter Ferdinand, and Tinódi even included extra strophes to praise him in the older songs. ${ }^{23}$ Ferdinand was aware of the importance of such a propaganda tool to convince the Hungarian nobility to support his cause. Already in the fifteenth century, Habsburg politics made intensive use of political poetry. ${ }^{24}$ There are no proofs that Ferdinand ordered or sponsored the songbook, but it is plau-

\footnotetext{
19 Varjas (1959).

20 Today 14 surviving exemplars of the book are known, which is a huge number compared to other secular books of the period.

21 Chronicles compiled as a chronologically ordered collection of individual historico-political songs were widespread in German literature, see Kellermann (2000) 55 .

22 István Vadai argues for the second hypothesis.

23 Vadai (2007) 281.

24 Brednich (1974-1975) 147-148 cites several German historical songs written to celebrate the glorious victories of Emperor Maximilian in the first decade of the 16th century.
} 
sible that he (or one of his Hungarian supporters from the high nobility) did so, and also that the king ennobled the poet in recompense for his 'poetic propaganda'. The poems of both parts of the songbook were popular, if we can trust the indications of the tunes that were reused in later poems, and it seems that the melodies of Tinódi's miscellaneous poems were even more widespread than those of the rhyme chronicle: among the eight songs of the first part, four songs were models for six different pieces, while five of the fourteen songs in the second part were imitated by nine poems. ${ }^{25}$

Two other great collections of historical songs of the period should be mentioned. The Hofgreff songbook appeared in the same year as the Cronica, but included only biblical histories. Gáspár Heltai's Cancionale was printed 20 years later, in 1574, one year after Sir Philip Sidney's travels in Hungary. The publisher, Gáspár Heltai, included six of Tinódi's songs, all belonging to the first section, either because the report song was already in decline by that period, or because of the lasting popularity of Tinódi's poetry. No longer relevant as news, they became classics of a genre and joined the other historical poems, together with songs treating plots from medieval Hungarian history. ${ }^{26}$

If we look for specific patterns in the Hungarian report songs, all formal criteria of the report song can in fact equally be found in other historical or epic songs of the period. The simplicity of the strophic structure, the use of morphemic rhymes, the melodic accompaniment, are valid criteria for all historical songs in the broad sense of the term. The length of a poem could vary from around 40 to over 150 strophes, with some extremely long pieces over 600 strophes. The strophes are, in Tinódi's work and that of most of his followers, connected with an acrostic, giving the name of the author, sometimes a short political or moral message, or even a brief summary of the plot. ${ }^{27}$

25 In fact, one report song from each of the two parts was imitated by at least four songs: the complaint on the battle lost at Temesvár, composed in 1552, and the song on the victorious battle at Szalka, composed in 1544. The first was reprinted by Heltai in 1574, probably advancing its popularity.

26 Nevertheless it remains still unexplained why his poems published in the Cronica were not copied in manuscript songbooks in the sixteenth and seventeenth centuries.

27 Acrostics are rather common in all genres of the Hungarian poetry of the period. It is not clear whether their constant use in Hungarian is due to medieval Latin or to early modern German influence. Brednich (1975) finds some German historical songs composed with acrostics, but it is not so widespread, and for instance in the Meistersingers' lyrics it is exceptional. In another article I argued that this is really a specific pattern of Hungarian poems from the beginning of the 16th century, and its practice might be considered as a proof of the authors literary culture and an important level of their education, see Seláf 2017. 
The report songs are normally written to highlight a recent event, taking it out of the flow of time and elevating it to the status of a memorable fact, comparing their matter to important historical moments, and underlining the whole with superlatives and hyperbole. While composing his songbook, Tinódi inserted a prologue to his longest composition, the Siege of Eger, about the successful defence of Eger against Turkish invasion. ${ }^{28}$ The prologue enumerates six of God's miracles: five battles described in previous pieces in the songbook, and the sixth, the one that will follow the prologue.

Bator legyen hatodic nagy chudaia

Isten mint lőn Egörnec megtartoia

Kiről énököm leszön megvalloia

Chiendességben chiac legyen meghalloia.

Ebből vitézöc soc iot tanulhattoc

Szalot hazba mi szükség meghallyatoc

Minden igyetökben mint forgolodgyatoc

Hogy io hirben nevben maradhassatoc. ${ }^{29}$

Let us tell as the sixth miracle how God defended Eger, as my song will testify, if in silence someone will pay attention to it. From this song you, oh knights, can learn what is needed in a besieged country, and how to act with endeavour in the hope of keeping your good reputation.

Surprisingly, battles lost by the Christians are also found among the miracles: It is not especially God's favourable intervention that qualifies a miracle. ${ }^{30}$ Tin-

28 Eger (called Erlau in German), is an important fortress besieged several times by Turkish forces in Northeast Hungary, not to be confounded with Eger in Bohemia. Peter Burke referred to this poem.

29 Sebastian Tinódi: Eger vár viadaljáról való ének história, vv. 33-40, Tinódi (1554) passim.

30 This is even more surprising if one considers Kellermann's observation that in German the military fiascos could not become the matter of the historical songs, cf. Kellermann (2000) 312. On the other hand Brednich (1975) 184-191 stresses the importance of the sensational events as topics of the Zeitungslieder: Tinódi could also be influenced by this other type of literary product diffused on broadsheet, and not only by the historische Ereignislied, if Brednich is right when he makes a distinction between the two genres. Brednich uses the categories of Sensationslied and Prodigienlied too. See on similarities between Tinódi and the contemporary German Zeitungsgesang also Béla Pukánszky's article (1927). Pukánszky finds similar rhetorical devices in the biblical historical songs composed by Tinódi and the Zeitungslieder. Remember also what Tinódi said in his Prologue about the importance of news: no matter if good or bad, writing about them is a pleasure. 
ódi's perspective is that of the historian. On the one hand, he describes events in the order in which God's will arranged them. On the other, to ennoble the battles he describes, he elevates them to the status of miracles. This term, taken from religious discourse, suits a performer seeking to make an impression on his audience.

Oh mely jelös hat chudac történtenec

Cronikaban hasonloc sem leletnec

Kikről Vilag vegig megemléköznec

Magyaroc közt mely veszödelmec lönec. ${ }^{31}$

Oh, six so important miracles happened, that you cannot find anything similar in the chronicles. They will be commemorated until the end of the world, all these disasters for Hungarians.

Among the motifs of the religious historical songs, Tinódi uses in his report songs the popular parallel with Jewish history. At the end of the Siege of Eger, he refers to Saul, who was lost because he did not fear God's anger: In Tinódi's time, too, he suggests, many notorious people died for such presumption. In the Song on the Battle of Szalka he repeats the commonplace that the Turkish calamity is God's punishment for Hungary's disobedience to His Laws. ${ }^{32}$

The simple metrical forms Tinódi used were widespread, and it seems reasonable to suppose that the popularity of his poetry furthered that of the forms. Among the other poems representing the genre, the majority use the naaaa and 12aaaa forms, dear to him. Only at the very end of the sixteenth century do we find a report song using the new, fashionable Balassi-strophe (aabccb$d d b, 667667667$ ), so called because it was invented by Bálint Balassi and first employed in his Petrarchist love-poetry. ${ }^{33}$

Having presented the patterns of Tinódi's poetry, I will now consider how closely (or otherwise) German and Hungarian historical poetry of the sixteenth century were related to one another.

$31 \quad$ Varjas (1962) passim.

32 On the parallel of Hungarian and Jewish destinies see Öze (1991).

33 This is the Epinicia Pálffy Miklós és Schwarzenburg diadalmáról, composed by Márton Gyulai (RPHA 1029 Nagy győzedelemről). All report songs are in monorhyme quatrains, except three pieces (one of them, in monorhyme tercets, is composed by Tinódi). 

Hypothesis I: German Influence on Hungarian Report Songs

The comparison of the two poetical traditions is helped by the fortunate fact that, in some cases, the same events of the Turkish war were reported in a German and in a Hungarian song. ${ }^{34}$

For example, the first item of Tinódi's Cronica, the Erdéli história (Transylvanian history), composed in 1553 according to the colophon, summarizes briefly the political events from János Szapolyai's death in 1540 to 1551, and gives a long presentation of the war events and diplomatic negotiations of 1551. A German historisches Ereignislied (Was wöll wir aber heben an?) of 1551, published in the same year in Nuremberg, treats of the same events. ${ }^{35}$ While Tinódi's chronicle is composed of 1,676 verse lines, the German song, written in Transylvania by Paul Speltacher, a lansquenet (soldier, Landsknecht) from Hall who participated in the battle, has only 235 lines. ${ }^{36}$ Tinódi moves in the narration to 1550 in line 297 , and to the year 1551 in line 658 , which means that almost two thirds of his text are dedicated to the same events of 1551 to which the German poem is devoted in its entirety. While the latter was published in Germany almost immediately after the events, Tinódi had a larger perspective, enough time to edit and modify his composition before publishing it in 1554 , and far more to report, thanks to his access to the versions of other eye-witnesses. Speltacher shares his experiences from his own point of view. He blames the treason of Giorgio Martinuzzi and the Hungarians in negotiating with the Turks, and exalts the virtues of the German soldiers. Tinódi gives a (probably) more objective, or at least more distanced report of the events.

Another text with a double is György Szepesi's Historia cladis turcicae ad Nádudvar, also known as Sásvár bég históriája. ${ }^{37}$ It describes the events of a whole year, covering the Hungarian defeats and victories of 1580 . The most important battles are also narrated in a shorter, contemporary German Lied of 31 strophes with the incipit Ein newes Lied zu singen / das wöllen wir heben an. The song was by Caspar Bschlagngaul, according to the critics a soldier serv-

34 For example the Hungarian poem Szükség ezt megírnom és meggondolnom attributed to János Szerdahelyi Imreffy (Stoll and Klaniczay (1959) 31) has a parallel in a German song preserved in the manuscript diary of a Saxon burgher of Transylvania, Simon Czauck.

Republished first by Schmidt (1971) 27-34, and following this edition by Kobzos Kiss (2008). Maria Dobozy published recently an important article on the story of the battle of Lippa as it is represented by Tinódi and Speltacher. For further parallels between the two songs see Dobozy (2013).

36 The colophon refers to the text as a 'liedlein' in strophe 47 .

37 Ács (1999). 
ing at Eger. ${ }^{38}$ The major difference lies in the chronological framing of the two stories. The German Lied concentrates on a battle near Nádudvar lasting three days, while the Hungarian poem (138 strophes) commemorates all the important encounters between Christians and Turks in Hungary during the year 1580 . Printed in 1581 , it is very close to the events, like the German song, printed in Prague in 158 o.

György Szepesi's Historia cladis turcicae presents some important features of the report song. Like most, it contains an acrostic, but only a short one, spread across its first seven strophes: the family name of the author (Tinódi used much longer acrostics, most of the time in Latin). ${ }^{39}$ Like Bschlagngaul's text, it has a colophon giving details of the date, motivation and place of composition, as was common in both the Hungarian and the German traditions. Like some other pieces of the genre, besides being a chronicle of events it is a glorification of a patron, Ferenc Geszti, who fought in the battles of the given year. His role was very modest according to Bschlagngaul and other contemporary sources. Tinódi did the same when he commemorated the imprisonment of Bálint Török, his patron, in two different songs, probably to fulfil an order given by the family of the prisoner.

In Szepesi's song the antagonist receives special attention. The plot describes the battles provoked mostly by the vengeful Turkish bey, the renegade Shasüvar, who after his first defeat wanted to repair his reputation. This is the only source to describe the Turkish leader of $158 \mathrm{o}$ as a Hungarian apostate, a Christian who denied his faith. This observation allows Szepesi a long digression on Jewish priests and leaders of the Old Testament who betrayed their homeland. The Turkish calamity is presented as a punishment. As we have already noted, Tinódi's songs use biblical motifs and the epic songs based on biblical plots also contain modern historical references. Szepesi refers to the Jewish-Hungarian community of destiny several times, for instance asking the Lord to punish the renegade bey as he did Sennacherib, who was killed by an angel (II Kings 1819). This biblical parallel, together with events from national history, occupies much the same place in the Hungarian songs as the Matter of Britain and the Matter of France do in the Italian and French epic poems. In this instance the

38 Ein news liedt dem Scharmützel und Niderlag, so fast einer Schlacht zuvergleichen, wider den Blutdürtstigen Türcken geschechen in Ober Hungern den 16. und 17. TagJulii, Prague, Michael Peterle, 1580. App. H 480. The name of the author is known from the colophon, strophe 31: "hat Caspar Bschlagngaul in Erlaw gesungen / sein Namen darff er wol sagen." For the figure of the Landsknecht-writer, frequent in the German Ereignislieder, see Kellermann (2000) 320 . 
Hungarian past (to be precise the glorious reign of King Mathias) is recalled by the melody, indicated in the printed version: it is the melody of another historical song, Ambrus Görcsöni's Árpád vala fó az kapitánságban (“Árpád was the leader of the army"), composed before 1568 .

On the German side, Bschlagngaul justifies his song by saying that Hungary has not seen a great Christian victory like the one he commemorates for a long time. ${ }^{40} \mathrm{He}$ emphasises the high deeds of the German soldiers fighting against the Turks, and mentions five figures by name, 'Herr Carl Rueber der Held', captain of Kassa, leader of the Christian army, some Hungarian officers (strophe 15), and a certain 'Barbier Andrasch, ein Ritterlicher Held' (s. 24), a Hungarian barber who distinguished himself in the battle. Szepesi dedicates four strophes to the heroic death of an unnamed German soldier, but in his narrative, beside the figure of Shasüvar, it is Hungarian heroism that dominates. His poem describes the cruelty of the Turks in a rather naturalistic way, and describes Christian cruelty similarly while finding it praiseworthy. ${ }^{41}$ In Bschlagngaul's poem the constant epithet of the Turks is blutdürstig, bloodthirsty. He does not need the character of the renegade, confining himself to the simple antagonism of Christians and Pagans to motivate the action. He too offers a parallel with Jewish history, but for him it is an argument for trusting in God's mercy:

Wie hat er [i.e. God] Pharao den Egypter / im Roten Meer ertrenckt / Josua wie Er streit wider fünff König / ihr Christen das bedenckt / Also thut er hoch helffen / die sein Wort rein bewarn / das haben wir Exempel an den Alten vor 3000 . Jaren.

Strophe 29

How God drowned the Egyptian Pharaoh in the Red Sea, how Joshua fought successfully against five kings- Christians, reflect on this! In the same way he will help those who keep his word pure. We have an example of this in the ancients, 3,ooo years ago.

In our next example the revolt against the prince of Transylvania in 1594 and the execution of the Hungarian aristocrats Boldizsár Báthori and Sándor Kendi

40 "Billich soll man Gott loben / in seinem Himmelreich / Das in langer zeit nicht geschehen / in Ungern ein schlacht dieser gleich / Unnd auff der Christen seiten / blieben so wenig person / thut Got uns hülff bedeuten / wenn man es wil sehen an" (strophe 27).

41 Brednich observed the same phenomenon in another German historical song composed in 1592 on the Turkish war in Croatia, see Brednich (1974-1975) 152-153, and in some other earlier songs supporting Emperor Maximilian's wars, 146-147. 
was narrated in two songs, one in German and one in Hungarian. The title of the German text is typical for the historische Ereignislieder published in print in the German speaking area: Ein schön und lustig Historia wie Gott der Allmechtig Bathori Sigismund dieses armen Sibenbürgens Fürsten wnnd L.H. wunderbarlich erettet hat von des Teuffels Tyrannen Wnnd aller Verretter Hand, in gesangweis verfasset auff die Ungerische nott zu singen, oder Nu freiyet gottes etc. ihm Jar 1596 allen armen Christen zum seligen trost in dieser unseligen Welt. It is noteworthy that the execution (commemorated in the diary as well) took place on the 3 oth August 1594, but the song is dated from 1596 and is written down in the diary among that year's events. If the dating is correct, this song is not a typical, newsletter-like text, for two years after the event no one could think of it as a novelty, all the more so if the target audience was the German-speaking community of the country. The Hungarian report song, dated from 1594, equally supports the prince's cause. The editor Orlovszky supposes that both songs were composed at court. Obviously, both compositions support the interests of the prince, Sigismund Báthori, nevertheless it cannot be proved that they were commissioned by him. The Kendi family was in favour of maintaining the peace with the Turks, while the prince wanted to fight against them in a Habsburg alliance. The constraints of the genre obliged the authors to support the cause of a good Christian prince, fighting against the pagans. In this case the German poem is even longer (172 strophes) than the Hungarian one (110), which probably means that the German song was not supposed to be printed on broadsheet. We can formulate the secondary hypothesis that this particular length in the chronological frames and in the number of verses could have resulted from the influence of the neighboring Hungarian poetry on this Transylvanian Saxon song.

As we have seen, although many Hungarian report songs can be found focusing on only one specific event in the ongoing war between Christians and Muslims, the difference in length is typical of the Hungarian and German poems of the same character (except in the case of our last example). The Hungarian poems of the period, even simpler in their form than their German counterparts, had a tendency to be verbose: prologues, epilogues, moral commentaries embellish the narration of the facts. There are further potential explanations for this difference. Firstly, we may argue on the basis of a generic difference by pointing out that some German historical poems are more lyrical in character: in these, the historical fact is only the background for the song, as in the famous mourning song on the death of Louis II. ${ }^{42}$ These texts are more like historical ballads, and their effect resides more in the brevity, the implicit message, the 
missing links in the narration, and the strength of the expression. ${ }^{43}$ Secondly, with regard to the medium: a poem published in a broadsheet could not survive very long from a commercial point of view. And thirdly, it is reasonable to suppose that the German public was less keen to inform themselves in detail about military events in Hungary via this type of poem; a little information could satisfy their curiosity.

Before estimating the real impact of German literature on Hungarian poetry in the case of this genre, it is worth presenting an example of Italian politicohistorical poems as well. This literature, like the German traditions discussed, is older and richer than the Hungarian, and presents far earlier parallels to the Hungarian report songs. ${ }^{44}$

There is at least one more genre in European poetry broadly related to the Hungarian historical song, the Italian cantare. ${ }^{45}$ It too is of obscure origins. It is also strophic but it is associated with a specific form not as simple as the Hungarian

in the German songbooks of the sixteenth century (Ambraser Liederbuch, Heidelberger Liederbuch, etc., see Classen (20o1), and Van Liliencron (1966) vol. 3, 562-563). This song blamed János Szapolyai for the king's death, and in this way supported the Habsburg's claim to the throne. This poem is frequently labelled as a historical ballad, a genre with rather fixed constraints in the German poetry of the late medieval period. My reasons for mentioning it here are backed by its propagandistic character and the long-lasting actuality of its political message due to the Hungarian nobles' constant opposition to the Habsburg dynasty. Though this circumstance must have contributed to its popularity, the main reason was certainly the poem's balladic character: its short length and strong sentimental effect. See on the category of historische Balladen Kellermann (2000) 103-104. On other German songs about the battle of Mohács see Seláf - Tóvizi (2014), Seláf (2016).

43 But of course I do not intend to say that all German Ereignislieder are historical ballads. In another essay I will try to compare the Hungarian report songs with the long, strophic Reimchroniken, in order to check their resemblance in time-handling and using other narrative techniques.

44 The level of literacy in sixteenth-century Italy or France was much higher than in Hungary. Comparative analysis may become more relevant if we take into account this shift in the evolution of the literatures.

45 The affinity of the registers has been remarked upon by several scholars from the 1970s, but in spite of the structural similarities the filiation of the Hungarian historical song as a genre derived from the cantari could never be proven Zemplényi ((1998) 54) refused to analyse the common patterns in them, with the argument that the Hungarian historical songs were exclusively under German influence. Hopefully, the closeness of the subjects may help us to understand how similar the constraints of the two minor genres cantare storico and tudósitó ének were to each other. 
quatrains, the ottava rima (nabababcc), which was probably first used by Boccaccio, and has a wide thematic spectrum. In spite of its presumably humanist origins, the form is often considered a typical expression of popular folk poetry, used by minstrels active in the cities to present their compositions at fairs and popular feasts. The different thematic groups of the genre include knightly (sometimes Arthurian), religious, and heroic epic cantari. A small subgroup of cantari (cantari storici) uses historical material, similar to the report songs. Some of them were collected and edited under the common name guerre, with a special volume consecrated to the wars against the Turks. ${ }^{46}$ In spite of their name, the cantari were probably mostly recited rather than performed with a melody.

One poem in the corpus deserves our special interest since it addresses an important event of Hungarian and European politics, the unsuccessful siege of Belgrade by Turkish forces in 1456. The Istoria del Gran Turco cuando fo roto a Belgrado in Ongaria, composed shortly after the events, probably by a Paduan professional minstrel (cantastorie) linked to the Franciscan friars, celebrates, rather unrealistically, the glorious victory, resounding throughout Christendom. ${ }^{47}$ In the cantare, after his defeat the Turkish emperor abjures Mahomet and accepts the Christian faith. The war's events are described very briefly, and with few protagonists; John Hunyadi, John of Capistrano and the Turkish emperor are what is needed. The 62 stanzas proceed by frequent repetition of verses, half-lines, and metaphors. Stanzas are often connected by the recurrence of a word or phrase, placed in the first or the last line of a stanza, in the following stanza. ${ }^{48}$ These marks are clear signs of oral presentation, probably helping memorization, and are based on the poetical heritage of the genre.

Surprisingly, the real protagonist of the poem is neither John Hunyadi nor John of Capistrano, but the Turkish emperor, and the strength of the Christian faith is proven by the example of his conversion. ${ }^{49}$ John Hunyadi is presented as reluctant to fight because of his age, like the aged Charlemagne; scared of the Turkish menace, he is convinced by his peers to engage in battle, where he fights vigorously with the help of the Franciscan and future saint John of Capis-

46 See in Beer, Diamanti and Ivaldi (1988-1989), especially volume 4, Guerre contro $i$ Turchi: 1453-1570.

47 Cornagliotti (1984). This text is missing from Marina Beer's edition.

48 Repetition of a word of the last line of the stanza in the first verse of the following strophe was widespread in the lyrics of the troubadours: they call it coblas capfinidas. Two stanzas beginning with the same word are coblas capdenals in this terminology, but this pattern is very simple, and rather frequent in every kind of narrative strophic poetry.

49 This motif recalls Luigi Pulci's later satirical poem Morgante, where Orlando defeats the pagan giant Morgante and converts him to the Christian faith. 
trano, who is the real leader of the Christian army according to the cantare. All this suggests that the author was connected with the Franciscan friars. It is no surprise that about one hundred years later a Hungarian historical song by Mátyás Nagybáncsai (1570), dedicated to the memory of John Hunyadi, sees the roles played by the participants in an absolutely different way. ${ }^{50}$ Here it is Hunyadi who tries to encourage his soldiers:

A megröttent népet kezde János Wayda illy szóval bíztatnia, Szerető fiaim, miért ilyettetek meg? Nekik mondja vala, Tudjátok, ezeknek nyakokon jártatok az én hadnagyságomban, És a ti fegyvertec nem volt erőtlen ő ellenek az hadban.

The voivod John has begun to motivate the frightened soldiers with these words: My dear sons, why are you afraid? He tells them: You may remember how we fought together against these [Turks] when I was only a sergeant. And your weapons were not weak against them.

The Italian author also makes a direct reference to the matter of France, when he says that if every Christian fighter could be like Orlando in the battle of Roncevaux, it would have been enough to defeat the Turks (s. 40: 'El basterebe zaschuno esser Orlando / quando quela batagia che fo in Ronzivalle'). Besides the conversion of the emperor, the song recounts another miraculous event, the appearance of a comet (Halley's Comet) in the sky over Belgrade, as a premonitory sign of the Christian victory. The pagan army is full of renegades, speaking different languages, almost keener on destroying Hungary than the Turks themselves..$^{51}$

It is difficult to measure the real impact of German literature on Hungarian in the case of this specific genre, because the critical discourse was totally differ-

\footnotetext{
$50 \quad$ Szalády (1890) 27-54.

51 I do not agree with the editor Cornagliotti ((1984) 16), who supposes that 'renegati' means simply pagans in most cases. I think the presence of renegates (traitors) is motivated by epic tradition, as in the preceding examples. It is a matter of genre, even if they play no special role in the poem. At the same time, we know that the Turks recruited their army from the population of the countries they invaded, so most of their soldiers were in fact actually renegades.
} 
ent in both cases. While little vernacular poetry other than the historical songs has been conserved in Hungary from before the 156os, in Germany the profusion of literary texts of the same period relegated historical songs for a long time to the realm of folklore studies. ${ }^{52}$ On the other hand, it seems to us that the Italian cantare, while offering structural parallels to Hungarian songs, cannot really be regarded as a potential model that could have had a real impact on their formation.

Despite the evident diversity of the above-mentioned texts, several motifs are common to most of them, often related to features of the plot. For example, betrayal and traitors appear in almost all examples. Renegades are present in the Istoria del Gran Turcho and in the Historia cladis turcicae. The author of Frölich will ich singen blames the Hungarian nobles for King Ludwig's death at Mohács in 1526. In war, treason is the greatest villainy; Ganelon casts a shadow over every historical poem..$^{53}$ According to these poems, conflict at any level must reflect the struggle of Good and Evil. ${ }^{54}$

The war narrative is strictly linear in all poems considered here. The traditional enumeratio of troops is also frequent; it has a twofold effect, allowing the poet to underline the historical accuracy of his testimony, and perpetuating a long-established epic practice.

In the Hungarian report songs and the German historische Ereignislieder, as in the cantari storici, the claim to the veracity of the narration is constant. The guarantee of veracity is either the testimony of the poet who speaks as a witness (in the German texts, the lansquenets Bschlagngaul and Speltacher) or the trustworthy report of participants (as in Hungarian songs, see Tinódi), and at other times a certain 'book', a written source for the poem. This may be sometimes fictive, as when the Istoria del Gran Turco mentions a copia:

... che zaschaduno dinota a questa mia favela

chomo la dita copia parla e sì raxonax,

Strophe 7

Everybody should listen to my tale; how the recited copy tells and explains [the story].

$5^{2}$ Similarly, the Italian cantari are frequently subjects of folklore studies, see recently Picone and Rubini (2007).

53 It is not surprising that the parallel Hungarian and German songs discussed above were dealing with the treason of the Kendi family. In the absence of a warlike conflict, this ignoble act was an appropriate topic for a report song or Ereignislied.

54 On the conflict between the black and white presentation of the adversaries in the German historical songs and the claim of veracity, see Kellermann (2000) 316. 
It is impossible to decide whether this denotes some kind of a source, or the written version of the orally presented cantare, in the hands of the minstrel who is reciting it. I incline to read it as an indication of the scenic character of the text, like the frequent invocations addressed to the listeners (usually called 'tuta bona zente'): the public performer shows his audience the copy of the original he has in his hands. It is interesting that the narrator uses the term favela (fable, story) in reference to his work, suggesting that, for him, there was no contradiction between historia (see the title) and fabula. The fictitiously staged closeness to the narration ${ }^{55}$ remains constant, but needs sometimes to be supported by the authority of a written source. Claims to veracity and the wish to present sensational news are often contradictory; nevertheless, they are both present in these poems. ${ }^{56}$ Brednich distinguishes between historische Ereignislieder and Zeitungslieder on the basis of content: sensational events such as an earthquake, a great fire, a comet, a tremendous murder are described in the second category, historical facts, battles and wars mostly in the first. ${ }^{57}$ It seems, though, that the sensational, exaggeration and miracles are also constantly used in historical songs reporting recent military events, in each tradition. This is partly a result of the exemplariness of the narrated events. Nevertheless, the accuracy and number of the data (dates, names) is not the same in the three traditions: there are much more in the Hungarian and German songs than in the Italian example. But all these texts play a propaganda role against the pagans, celebrating outstanding heroes and their victories as examples to follow for the ordinary soldiers of Christ.

Stylistically, the most salient common point is the importance of repetitions in each text. There are however important differences in the way the poems use this technique. It is probable that repetition was seen by the authors as a conscious feature, following the stylistic ideal of the genre, strengthening its (sometimes pseudo-) oral, publicly performed character. The wide range of possibilities of repetition given partly by the strophic form provides a specific character to these poems as opposed to those in rhyming couplets. Though these Ereignislieder do not have any refrain (the most common hyperstrophic repetitive structure of late medieval lyrical poetry), they do proceed by frequent repetition: of formulas, verses, identical grammatical structures. The Istoria del Gran Turco contains the greatest number of these, but it does not necessary mean that this was a more archaic method of composition than that

55 Kellermann's 'fiktiv inszenierte Ereignisnähe', Kellermann (2000) 328-329.

$5^{6}$ The goal to offer sensations to the public is often obtained by heightening the importance of otherwise mediocre facts.

57 Brednich (1974-1975) 188-189. 
of the two other corpora, indeed the presence of coblas capfinidas in this text (admittedly this strophe-binding hyperstructure is not used in a regular way) attests to a more elaborated compositional range than the tools used by our Hungarian or German authors, who do not link strophes in this way. The only analogous feature Hungarian report songs can offer is the acrostic, while for the most part the German historical songs' formal unity was guaranteed solely by the format of the broadsheet, limiting the length of the poems to some extent.

As we said above, the Hungarian report songs share several patterns with the German historische Ereignislieder. Their relationship to the melody is very similar. These poems are either contrafacta of simple popular melodies, or if they claim originality of form, are composed in rather simple strophic structures. ${ }^{58}$ The Italian poetic tradition, with its strongly normative poetic standards and almost exclusive use of seven-, nine- and eleven-syllabic lines, resulted in the use of one specific form, the ottava rima, for every cantare. Formal originality at the strophic level was impossible in this system, and we cannot tell anything sure about the musical performance of that genre.

The Hungarian corpus has one specific feature, related to text length. These poems are generally integrated into the larger national historical discourse, a role that they may already have played during the unknown prehistory of the genre. Although Hungarian heroic poetry of the Middle Ages does not survive, presumably its topics were taken from national history, as Galeotto's and Sidney's brief references suggest. Another possible explanation is that this feature reflects the strength of the model offered by Tinódi, with his wide view on history, in the Cronica. His imitators could have accepted that a report on a recent event must be contextualised, being only a significant parcel of Hungarian history, 'one miracle among others'. The German Ereignislieder are more straightforward and I am not aware of any example that includes a wider his-

$5^{8}$ Brednich cites Erich Seemann's list of the patterns characteristic to the Zeitungslieder, which contains the remark, that in the sixteenth century the melodies of German historical songs are contrafacta, they frequently use complicated strophic structures of Meisterlieder (Brednich (1974-1975) 186). But later, in another chapter, Brednich remarks that 'Meistersangerische Strophenformen sind im Liedflugblatt nur sehr spaerlich vertreten' (256). Even if the strophic structures are more complex that in the Hungarian tradition, we can assume that regurarly they are less artistic than the Meistergesang's forms. Borrowing of melodies is very frequent, as it can seen in the indication of the tune (Tonangabe) given by over 170 songs collected by Brednich. Some popular melodies, like Von erst so wöl wir lobern Maria die raine maid or the Bremberger Ton and the Tollner Weise were used for over ten different Ereignislieder. Melodies and forms of religious songs were reemployed the most of the time, Brednich (1974-1975) vol. 2, 285-288. 
torical presentation of this kind. ${ }^{59}$ While the earlier medieval 'matter of France' appears in the fifteenth-sixteenth century Italian poems on contemporary military events, this is entirely absent from the Hungarian corpus. In the cantari, the narrative elements taken from the remote past are more like stylistic reminiscences than signs of an effort to integrate matter into a continuous national history.

Either the song-form takes the place of prose narrative as an archaic feature of Hungarian literature, or we can suppose an external influence. Or both may be true. One plausible model is a combination of narration with a fairly simple scholarly Latin formal tradition that made use of strophes, simple melodies and acrostics, as taught in late medieval Hungarian schools. This could have been combined with the techniques of propaganda poems written for a large public (like colophons or hyperbole and similarly extravagant elements), techniques that might have been copied from the contemporary German Liedpublizistik close to hand, or that may simply have been identical with it because both traditions shared a common late medieval religious discourse.

Brednich, in his valuable monograph, concentrates on the medium of the short print as determinant of this type of occasional poetry: for him, most of the specific characteristics of the genre are derived from this form of publication. ${ }^{60}$ Brednich drew scholarly attention to the specificity of these texts, their form and the medium. He and his forerunners succeeded in clarifying the interference of propaganda, the need for news and novelty, forcing the community's coherence by denigrating the common enemy, ${ }^{61}$ and the reuse of stylistic motifs from heroic poetry in the historico-political songs. It would however be misleading to present this genre exclusively as belonging to popular poetry. Sidney's and Puttenham's example, like the stylistic unity of all Hungarian poetry before Bálint Balassi's Petrarchist lyrics, could be proof that historical song was

59 In this respect the Hungarian songs remember more the Zeitungslieder than the Ereignislieder if we accept Brednich's definitions ((1974-1975) 187). According to him the Zeitungslied observes the events from distance, and adds moral commentaries to the narration.

6o The only occasion when he mentions the German influence on Hungarian poetry, he observes as the greatest difference between them that Hungarian Zeitungslieddichtung stayed for a longer time in the orality, and printed copies of it were rare (Brednich (19741975) 191).

61 Brednich ((1974-1975) vol. 2, 140-141) is citing Hans-Georg Fernis' work (Fernis (1938)) on the political poetry of the German-speaking Swiss communities, aiming to consolidate the estate by the help of stylistic references to the medieval heroic poetry (Heldendichtung). Galeotto's description of Hungarian historical songs fits exactly to this image: this tradition was strengthened by the introduction of printing and the massive German influence due to the Reformation and the Habsburg political domination. 
in some circles considered one of the highest genres of literature. The traditionalist Hungarian poetry, Sidney's own military ambitions and stylistic ideals found an echo in Aristotelian Renaissance poetical treatises praising heroic epic poetry. It means also that approaching these poems simply as part of popular culture and as counterparts of the highly sophisticated courtly poetry may be misleading, if we take into account the appreciation of the historical poetry by the early modern poets and theoreticians.

Finally, as regards the consequences of using pre-existing lyrical forms and melodies, or at least strophic forms, it can be concluded that despite the authors' explicit claim to be objective and credible, and despite their hidden propagandistic motivation, they use thematic and stylistic features attached to the form they reuse. These contemporary historical poems in Hungarian, German, and Italian share their own common relationship to fiction, different from that of other poetic genres and also from that of prose chronicles. They borrowed some of their stylistic motifs from heroic epic texts, as we saw with Tinódi's reference to Virgil's Aeneid. The authors frequently added oral exclamations typical of minstrels to their texts, pleading for silence or asking for wine and money. Most of the poems discussed here contain some references to antiquity, quotations, and greater or lesser traces of the national heroic epic. All this helps to provoke an atmosphere of literary reminiscence, and to evoke older heroic poetry, but it also gives a fictional character to the historical poems. Historical truth becomes poetic truth and is transformed by this change. Once the professional reader or singer is performing poetry, they can convince the audience, but their rhetorical tools have been selected in advance. The poet loses his credibility if he refuses to use the topoi of the traditional forms he seeks to revitalize. He must be a learned poet, with the advantages and disadvantages that this entails in respect of historical truth.

\section{Bibliography}

Ács, P. (ed.) 1999. György Szepesi: Sásvár bég históriája. In Régi magyar költők tára. XVI. századbeli magyar költók müvei, vol. 11, ed. P. Ács. Budapest: 157-172 and 429-443.

Beer, M., Diamanti, D., and Ivaldi, C. (ed.) 1988-1989. Guerre in ottava rima. 4 vol. Modena.

Brednich, R.W. 1974-1975. Die Liedpublizistik im Flugblatt des 15. bis 17. Jahrhunderts. 2 vols. Baden-Baden.

Brednich R.W. 1982-1983. Erziehung durch Gesang. Zur Funktion von Zeitungsliedern bei den Hutterern. Jahrbuch für Volksliedforschung 27: 109-133.

Burke, P. 1994. Popular Culture in Early Modern Europe. 2nd ed. Cambridge. 
Classen, A. 2001. Deutsche Liederbücher des 15. und 16. Jahrhunderts. Münster.

Cornagliotti, A. 1984. 'Istoria del Gran Turcho quando fo roto a Belgrado in Ongaria': un cantare quattrocentesco padovano. Atti dell'Istituto Veneto di Scienze, Lettere ed Arti. Classe di Scienze Morali, Lettere ed Arti 142: 7-38.

Dobozy, M. 2013. Two Cultural Perspectives on the Battle of Lippa, Transylvania, 1551: Whose Victory Is It? Fifteenth-Century Studies 38: 21-39.

Fernis, H.-G. 1938. Die politische Volksdichtung der deutschen Schweizer als Quelle für ihre völkisches und staatliches Bewusstsein vom 14.-16. Jahrhundert. Deutsches Archiv für Landes- und Volksforschung 2: 6oo-639.

Horváth, I. 2009. Szabács viadala. In "Látjátok feleim ..." Magyar nyelvemlékek a kezdetektôl a 16. század elejéig, ed. E. Madas. Budapest: 151-156.

Juhász, L. (ed.) 1934. Galeottus Martius Narniensis, De egregie, sapienter, iocose dictis ac factis regis Mathiae ad ducem Johannem eius filium liber. Leipzig.

Kellermann, K. 200o. Abschied vom "historischen Volkslied": Studien zu Funktion, Ästhetik und Publizität der Gattung historisch-politische Ereignisdichtung. Tübingen.

Kobzos Kiss, T. 20o8. 'Lippának erős vívása'. Paul Speltacher német zsoldoskatona szerint. In Tinódi Sebestyén és a régi magyar verses epika, ed. R.I. Csörsz. Cluj: 215224.

Von Liliencron, R. (1966), Die historischen Volkslieder der Deutschen vom 13. bis 16. Jahrhundert. 4 vol. Hildesheim (reprint Leipzig 1865-1867).

Madas, E. (ed.) 2009. “Látjátok feleim ...” Magyar nyelvemlékek a kezdetektől a 16. század elejéig. Budapest.

Orlovszky, G. 2007. A históriás ének. 1574: Megjelenik a Cancionale. In A magyar irodalom történetei. A kezdetektől 180o-ig, ed. L. Jankovics and G. Orlovszky. Budapest: 310-322.

Őze, S. 1991. 'Büneiért bünteti isten a magyarnépet'. Egy bibliaipárhuzam vizsgálata a 16. századi nyomtatott egyházi irodalom alapján. Budapest.

Picone, M., and Rubini, L. (ed.) 2007. Il cantare italiano fra folklore e letteratura. Florence.

Pukánszky, B. 1927. Sebastian Tinódi und der deutsche Zeitungsgesang. In Aus den Forschungsarbeiten der Mitglieder des ungarischen Instituts und des Collegium Hungaricum in Berlin. Berlin/Leipzig: 115-121.

Schmidt, L. 1971. Historische Volkslieder aus Österreich vom 15. bis zum 19. Jahrhundert. Wien.

Seláf, L. 2014. Épica y poesía histórica del Renacimiento en Hungría y en Europa. In Arroyo A. - Lombana A. - Pál F. Retratos húngaros: literatura y cultura. Madrid: 117128.

Seláf, L. 2016. A mohácsi csata visszhangja kortárs tudósító énekekben. In Farkas G.F. Szebelédi Zs. - Varga B. "Nekünk mégis Mohács kell ..." II. Lajos király rejtélyes halála és különbözö temetései. Budapest: 147-154. 
Seláf, L. 2017. Poétiques perpendiculaires: les acrostiches versifiés latins dans la poésie hongroise de la Renaissance. In Seláf L. - Noel P. (ed.), The Poetics of Multilingualism-La Poétique du plurilinguisme. Newcastle upon Tyne: 103-120.

Seláf L., and Tóvizi, Á. 2014. Ismeretlen illusztrált röplap a mohácsi csatáról. In Magyar Könyvszemle 130 (2): 261-271.

Stoll, B., Klaniczay, T. (ed.) 1959. Régi Magyar költök tára 17. Század, vol. 1. Budapest.

Szalády, Á. (ed.) 189o. Régi Magyar Költők Tára. XVI. századbeli magyar költők müvei, vol. 4. Budapest.

Vadai, I. 2007. A tudósító ének műfaja. 1554: Megjelenik Tinódi Sebestyén Cronicája. In A magyar irodalom történetei. A kezdetektôl 180o-ig, ed. L. Jankovics and G. Orlovszky. Budapest: 274-285.

Varjas, B. (ed.) 1959. Cronica. Tinodi Sebestien szörzese ..., Kolozsvár [Cluj, Clausenburg], 1554, Facsimile edition. Budapest.

Whigham, F., and Rebhorn, W.A. (ed.) 2007. George Puttenham, The Art of English Poesy. Ithaca/London.

Zemplényi, F. 1998. Az európai udvari kultúra és a magyar irodalom. Budapest. 